\title{
STYLISTIC OF THE QUR'AN: READING THE STORY OF SULAIMAN
}

\author{
Muhammad Afif Amrulloh ${ }^{1}$, Munirul Ikhwan ${ }^{2}$ \\ ${ }^{1}$ Universitas Islam Negeri Raden Intan Lampung, Indonesia \\ Jl. Letkol H. Endro Suratmin, Kec. Sukarame, Kota Bandar Lampung, 35131, Indonesia \\ ${ }^{2}$ Universitas Islam Negeri Sunan Kalijaga Yogyakarta, Indonesia \\ Jl. Marsda Adisucipto Yogyakarta, 55281, Indonesia \\ CorrespondingE-mail:afif.amrulloh@radenintan.ac.id
}

\begin{abstract}
This paper examines the stylistic of Sulaiman's story in the Qur'an and its chronology. The language style has a building in the historical social context of the Arab community when it came down to the Qur'an. This article aimed to find the chronology and function of each language style used in the story of Sulaiman. This study was a library research with descriptive and analytical data presentation methods. The primary data were taken from the Qur'an in Surah Shad (30-40). A hetorical and chronological analysis wass used in this research. The finding of this study showed that the rhetoric of Sulaiman's story in Surah Shad still used a high style of language. Based on these findings, a strong language style is a characteristic of the Sulaiman's story to strengthen the prophet's heart, console the prophet and give the encouragement of spreading da'wa of Muhammad. This study contributes to a complete understanding of language style.
\end{abstract}

Keywords: chronology, parole, rbyme, stylistics

\section{Introduction}

Story or legend is a form of the Qur'an in conveying messages ${ }^{1}$ or information to mankind. ${ }^{2}$ The narrative in Qur'an is dominant with linguistic, especially at the stylistic level. ${ }^{3}$ The messages conveyed with various attractive language styles can arouse the awareness of readers or listeners so that it can be understood easier. ${ }^{4}$

\footnotetext{
1 Akrimi Matswah, "Mustansir Mir and a Contemporary Literary Approach to the Qașaș AlQur'ān: Study of Qur'anic Story of Joseph”, Ulumuna, Vol. 21, No. 2, 2017, 391-411.

2 Shahir Akram Hassan, "Understanding Social Phenomenon From Qur'anic Verses", The Macrotheme Review, Vol. 3, No. 4, 2014, 36-44.

${ }^{3}$ Mohd Imran Khan, "Stylistic Dimensions in Translations of the Holy Quran into English with Special Reference of Surah Al-Fatiha", Journal of Education, Society and Behavioural Science, 2016, 1-9.

4 Laith Bany Melhem et al., "Text Line Segmentation of Al-Quran Pages Using Binary Representation", Advanced Science Letters, Vol. 23, No. 11, 2017, 498-502.
} 


\section{Arabiyât Jurnal Pendidikan Bahasa Arab dan Kebahasaaraban, 8 (1), 2021}

Therefore, the contents of Qur'an are dominated by stories of the past which are quite intensive. ${ }^{5}$ In the context of revelation, the narrative of the story in the verse of the Qur'an has its own significance. The Qur'ān is a reflection of the journey of Prophet Muhammad through various historical events. Every surah in the Qur'an will have a correspondence with the context in which it was revealed. ${ }^{6}$ The context of the passage of the Qur'an cannot be separated from literary discourse. The correspondence between the narrative of Al-Quran and the historical context ${ }^{7}$ that surrounds it is very visible in the historical content of the Makiyah-Madaniyah discourse. ${ }^{8}$ The story of Prophet Sulaiman in Surah Shad (30-40) is one of the representative objects historically. These verses are categorized as Middle of Makiyah in the chronology of Noldekke-Schawly and the late of Makiyah in Gustav Weil's calculations. The events of the Prophet Muhammad's migration to Ta'if around the year 620 AD became the benchmark for the dating of this phase.

There are still few studies on the rhetoric of Qur'an and its chronology, not many have studied the rhetoric of Qur'an in the story of Prophet Sulaiman with its chronology. The studies that have been carried out by previous researchers used various points of view and the focus of their respective studies. Ahmet Sait Sicak offers an in-depth analysis of the style study of Qur'an with tafannun as part of ijâz for a comprehensive interpretation of Qur'an. The problem is related to various kinds of language style variations in Qur'an, one of which is tafannun. Starting from the concept of tafannun which is still limited and having a restriction on the word meaning and it is related to the word iftinân in the framework of Badi. The writing itself aims to describe the meaning of tafannun, reveal tafannun's contribution to a better interpretation of Qur'an and examine the importance of tafannun in the realm of interpretation. Tafannun hopefully can help the readers to understand the meaning and read easily. Then related to literary devices used in tafannun include udul, iltifât, taqdîm and ta'khîr, changing utterances, using synonyms, similar words and adding words. ${ }^{10}$ The writing itself has not yet led to the stylistic stories of the prophets with their chronology.

Angelika Neuwirth, a great Western scholar who is an expert in classical and modern Arabic literature. She writes studies that focus on Qur'an not as a form of work or a permanent manuscript like after the death of the prophet, but is considered as a chain of oral communication conveyed by the prophet to the communities of

${ }^{5}$ Muhammad Hasnan Nahar, "Antagonist Figures in the Qur'anic Stories”, Afkaruna: Indonesian Interdisciplinary Journal of Islamic Studies, Vol. 15, No. 2, 2019, 254-80.

${ }^{6}$ M A S Abdel Haleem, "The Role of Context in Interpreting and Translating the Qur'an", Journal of Qur'anic Studies, Vol. 20, No. 1, 2018, 47-66.

7 Sayyed Mohammad Reza Ibnorrasool and Azam Dehghani, "Extra Letters in Osman Taha Line Their Positions and Their Causes in the Quran", Studies on Arabic Language and Literature, Vol. 4, No. 14, 2013, 1-18.

${ }^{8}$ Latifah Abdul Majid et al., "Attributes of Antioxidants as Inferred from the Makki and Madani Verses of the Qur'an", Al-Burban: Journal of Qur'an and Sunnab Studies, Vol. 4, No. 1, 2020, 31-42.

9 Ahmet Sait SICAK, “Kur'ân'da Benzer Mana ve Lafizlarda Tefennün”, Cumburiyet Ilabiyat Dergisi, Vol. 23, No. 2, n.d., 739-763.

${ }^{10}$ Ahmet Sait SICAK, “Kur'ân'da Benzer Mana ve Lafizlarda Tefennün”, 739-763. 


\section{Arabiyât Jurnal Pendidikan Bahasa Arab dan Kebahasaaraban, 8 (1), 2021}

Mecca and Medina. The steps taken by Angelika Neuwirth started from surveying the hermeneutical implications of reciting Qur'an as a mushaf and Qur'an itself. To justify the claim of orality of Qur'an, it is not limited to its function as mediality, but gradually acquires a theological dimension. Therefore, someone must trace the strategies which are adopted in Qur'an. First, the purpose is to justify its basic oral character as the legitimate of scripture and then to defy the other concepts of codified scripture. Neuwirth focused on the stylistic devices used to legalize text as transcendent messages and the discovery of reading media as a novelty in oral communication. The article demonstrates the rhetorical character of Qur'an through a comparison of the text of the Hymn of the Bible and the version of the Qur'an which is no longer a poetic praise from God, but a parenetic speech for the audience to believe. $^{11}$

Michel Cuypers reads the style of the language of Qur'an in the context of semitic rhetoric. The questions about nazm from Qur'an often arise in the study of the interpretation of Qur'an without any resolution. The study of the Bible has been faced with the same question about the apparent "abnormalities" of certain texts in the Bible. Therefore, scholars developed a method of text analysis, namely "Rhetorical Analysis" which involves theorizing the rhetorical composition rules of language as used in the Ancient Semitic world. These rules can also be applied to Qur'an and other ancient Semitic sacred texts. Through this study by Michel Cuypers, five letters or letter fragments are analyzed according to the Rhetorical Analysis paradigm, showing the very complex composition of these texts and also the explanation that aspects of their composition can be separated from their interpretation. He studied the style of Qur'an in the context of Semitic rhetoric which emphasized the reading of Qur'an in its original milieu. ${ }^{12}$ In contrast to this research in the chronology theory used, this study uses the theory of Qur'an chronology by Theodor Nöldeke-Schwally.

Azalia Mutammimatul Khusna discussed the scope of stylistics in the phonological aspect and all linguistic phenomena and tends to accommodate all existing definitions of stylistics from experts. He views stylistics as a critical approach that uses linguistic methods and findings in the analysis of literary texts. However, Azalia limits her studies related to stylistics to the aspects of phonology, morphology, semantics, syntax and imagery with the nuances or effects that they cause and the style of the storyline. The difference of the present study with this research is that although Azalia reveals the five elements in stylistics, it has not yet alluded on the chronological aspect of the story of Prophet Sulaiman in Qur'an as the unit of analysis in the research. ${ }^{13}$ Nur Padwisana, studied the language style of communication in the preaching of the story of Prophet Sulaiman with the Queen of Saba' and the

${ }^{11}$ A. Neuwirth, The Rhetorical Qur'an or Orality as a Theologumenon, In The Heritage of Arabo-Islamic Learning, After One Hundred Years, (Leiden Boston: Brill, 2016).

12 M Cuypers, "Semitic Rhetoric as a Key to the Question of the Naẓm of the Qur'anic Text", Journal of Qur'anic Studies, Vol. 13, No. 1, 2011, 1-24, https://doi.org/0812730.

13 Azalia Mutammimatul Khusna, "Kisah Nabi Sulaiman As Dalam Al-Qur'an (Analisis Stilistika)", UIN Sunan Kalijaga Yogyakarta, 2019. 


\section{Arabiyât Jurnal Pendidikan Bahasa Arab dan Kebahasaaraban, 8 (1), 2021}

dignitaries in Qur'an. The main problem raised is how the style of communication in the preaching of the story of Prophet Sulaiman and the Queen of Saba 'and the dignitaries in Qur'an. In communicating the story of Prophet Sulaiman, she did not directly reveal the procedures or rules of preaching the version of Prophet Sulaiman. Thus, the analysis of the language style of Prophet Sulaiman's preaching communication became the main concern of the researcher. She analyzed the language style of the context in a text in the story of Prophet Sulaiman and Queen Bilqis and the dignitaries of Qur'an in terms of rhetoric and style of language in the context of the verse. ${ }^{14}$

Another researcher, Mursalim, examines the style of the language of the story in the Qur'an, with a focus on the style of repetition of the story of the Prophet Musa by using stylistic analysis. The story of the Prophet Musa (as) is indeed one of the stories with the most repetition of stories in several surahs in the Qur'an, making it interesting to study from the perspective of the style of language. There are many stories concerning the Prophet Musa (as) in several surahs in the Qur'an; such as surah al-Baqarah, ali Imran, al-'Araf, al-Naml and so on. One reason suspected is because in the context of carrying out da'wah, there are many similarities in the social setting between Prophet Musa and Prophet Muhammad. ${ }^{15}$ Meanwhile, Suniarti Sunny limited the focus into four aspects, phonology, lexical, syntax and rhetoric. She concludes the stylistic elements that build the story of Prophet Sulaiman from these five aspects, then the flow of storytelling, the method of depiction, the characterization of the prophet Sulaiman and the series of events that occurred in it. This research aims to find the language style and meaning in Surah al-Rahmān. ${ }^{16}$ Some of these studies mostly focus on linguistic aspects. Not many studies have linked stylistics to context (diachronic analysis).

Stilistics or ilmu al-Uslub, is a study of the analysis of language style based on the choice of the writer or author in compiling their work. ${ }^{17}$ The style of language in Qur'an has the different characteristic from other Arabic literary works. Even the style of Qur'an language is presented in a distinctive way. The use of the language style of Qur'an is adjusted to the conditions or circumstances of the community when it comes down. Thus, the style of Qur'an language used in the Makiyah verse is certainly different from the Madaniyah verses or surahs. As stated by Nasr Hamid Abu Zayd that the language style in the first phase; the Mecca phase aims to lay the foundations of a new society. Therefore, at this time the text was focused on the formation of new

${ }^{14}$ Nur Padwisana, Moh Abdul Kholiq Hasan, and Ari Hikmawati, "Gaya Bahasa Komunikasi Dakwah Nabi Sulaiman dengan Ratu Negeri Saba' dan Para Pembesar dalam Al-Qur'an”, 2017.

15 Mursalim, "Gaya Bahasa Pengulangan Kisah Nabi Musa As. dalam Al-Qur'an: Suatu Kajian Stilistika”, Lentera, Vol. 1, No. 1, 2017.

16 Suniarti Sunny, "Gaya Bahasa Dalam Surat Ar Rahman (Kajian Stilistika)", Tesis, UIN Sunan Kalijaga Yogyakarta, 2014.

${ }^{17}$ Saleh Fadl, Ilmu al-Uslub Mabadiubu wa Ijrâtuhu, (Kairo: Mu’assasah Mukhtar. 1992), 103. 


\section{Arabiyât Jurnal Pendidikan Bahasa Arab dan Kebahasaaraban, 8 (1), 2021}

reasoning through tauhid and polytheistic creeds. Meanwhile, the second phase is the social development phase. ${ }^{18}$

This paper will examine the rhetorical style used in the story of Prophet Sulaiman in Qur'an using a rhetorical and chronological analysis so that the function of each language style used and its historical aspects will be found. The story of Prophet Sulaiman was chosen because besides being a prophet, he was also a popular king in ancient Arabic stories ${ }^{19}$ along with his story with a queen of Saba. ${ }^{20}$ In addition, the choice of the story of Prophet Sulaiman is because there is no repetition of the events in the verses that tell the story. The story of Prophet Sulaiman is found in several letter fragments; Surah Shad (30-40), al-Anbiya '(78-82), al-Naml (15-44) and Saba' (12-14) are narrated with their respective contents. However, this study is as specific as surah Şād (30-40). This study aimed to find the chronology and function of each language style used in the story of Prophet Sulaiman in Qur'an. This study concerns about the certain relationships with contexts that focus on linguistic aspects without neglecting the context. Thus, this study contributes to a complete understanding of language style.

\section{Method}

The study of the stylistics of the story of Prophet Sulaiman in Qur'an was carried out by using a library research which took the data source from the library. The data were obtained by using documentation techniques, namely based on literature, both in the form of journals and other research results related to the discussion of this study. This research is a qualitative research by presenting the data which is then analyzed systematically. Surah Şād (30-40) is the object of this research material as well as the primary data source which represents the story of the Prophet Sulaiman in Qur'an, while the formal object is the study of stylistics.

The data analysis technique was descriptive research that describes various data or problems and then analyzed by a stylistic approach in each verse that tells about Prophet Sulaiman in Qur'an. This study used stylistic theory to discuss the stylistics of the story of Prophet Sulaiman in Qur'an. Comparative analysis was used to compare the content and language style used in each letter of the story of the Prophet Sulaiman. A rhetorical and chronological analysis was also used in this research. Rhetoric analysis was to find the function of each language style, while chronology was to show the historical aspects of the dynamics of the prophetic mission.

${ }^{18}$ Nasr Hamid Abu Zayd, Tekstualitas Al-Qur'an, Kritik. Terbadap Ulumul Qur'an, Terj. Khoiron Nahdliyyin, (Yogyakarta: Lkis, 2005), 4-5.

19 Mohammed Nihad Ahmed, "The Issue of Translating Cognitive Semantic Content of Discourse", Journal of Tikrit University for the Humanities, Vol. 17, No. 7, 2010.

${ }^{20}$ Hamed Sedghi and Fatemeh Ganjkhnlou, "An Analysis of the Narrative Structure of the Story of Prophet Sulaiman (AS) and Queen of Saba Based on Greimas's Narrative Model”, Literary Quranic Researches, Vol. 4, No. 3, 2016, 23-46. 


\section{Result and Discussion}

The Personality of Prophet Sulaiman (Surah Shad (38) Verses 30-40)

The stylistic analysis used the classical theory based on al-mustawayat aluslübiyyah (aspects of stylistic analysis) ${ }^{21}$ on surah Shad (38) verses 30-40 found the selection of the form of Shigat Mubalagah (morphological aspects; al-mustawâ al-sharfì) ${ }^{22}$ and preliminary position a word in i'râb or al-taqdim wa al-ta 'khîr (syntactic aspect; almustawa al-nabwi an al-tarkîbî). ${ }^{23}$ The following describes some of these forms, namely:

$$
\text { ووهبنا لداود سليمان نعم العبد إنه أواب }
$$

"And to Daud, We gave Sulaiman,

An excellent servant, indeed he was one repeatedly turning back (to Allah)". (Surat Shad: 30)

$$
\text { إن...... }
$$

“.....Indeed, You are the Bestower." (Surat Shad: 35)

$$
\text { والشيطين كل بناء وغواص }
$$

"And [also] the devils [of jinn] - every builder and diver" (Surat Shad: 37)

Based on these three verses, the word awwâb in verse 30 uses the shigat mubalagab form. Qur'an chose the use of shigat mubalagah form instead of isim fấil form to show isim fá'il with a stronger meaning. The word in Qur'an follows the wazan fa'al so that it becomes the word 'amwab'. Sulaiman, as a servant, is always obedient to his God. Furthermore, the word al-Wabhâb in verse 35 also uses the form of sigat mubalagah. Qur'an chose the use of shigat mubâlagah form instead of isim fä'il form to show isim fá'il with a stronger meaning. The word in Qur'an follows the wazan fa'al so that it becomes the word 'al-Wabhâb'. The word gawâsh in verse 37 also uses shigat mubalagah form. Qur'an chose the use of shigat mubalagah form instead of the isim fấil form to show isim fấil with a stronger meaning. Thus, this word shows that the devils who were subjected by Allah to Prophet Sulaiman who had special strength.

The next aspect in al-mustawayat al-uslubiyyah (stylistic analysis aspect) is the syntactic aspect or al-mustawâ al-nabwi an al-tarkîb̂ิ. The discussions on the stylistic analysis of this syntactic aspect can be done around sentence structure patterns, repetition or repetition; both words, sentences or stories, as well as how the effect

${ }^{21}$ Eman Adil Jaafar, "A Stylistic Analysis of Two Selected Poems", Journal of the College of Education for Women, Vol. 25, No. 1, 2014; Haleema Rashid and Muhammad Arfan Lodhi, "Stylistics Analysis of the Two Translated Versions of the Holy Quran with Special Reference of Surah Al-Noor", Sciences, Vol. 6, No. 2, 2018, 88-110.

22 Muhammad Afiq Mahazi and Hakim Zainal, "Asas Pembentukan Kata Dalam Morfologi Arab:[The Foundation on Word Formation In Arabic Morphology]", Ulum Islamiyyah, Vol. 25, 2018, $55-63$.

${ }^{23}$ Umi Machmudah et al., "Epitome Solution to Nahw Instruction: Strategies toward i'rab Reading Abilities for Students", International Journal of Innovation, Creativity and Change, 2020. 


\section{Arabiyât Jurnal Pendidikan Bahasa Arab dan Kebahasaaraban, 8 (1), 2021}

appears on the meaning. ${ }^{24}$ In Surah Shad (38) Verses 30-40 the preliminary aspect of the position of a word in $i^{\prime}$ râb (al-taqdîm wa al-ta 'khîr) was found;

$$
\text { فسخرنا له الريح........ }
$$

"So, We subjected to him the wind blowing by his command..." (Surat Shad: 36)

The pronoun in verse 36 labu is before the word al-Rîh. This style of language al-taqdim wa al-ta 'khir serves to draw the reader's attention to the pronoun (d) which refers to the figure of Prophet Sulaiman. Then the aspect of presenting the elements of the story displayed in Qur'an generally includes three aspects, namely characters or actors, events and dialogue. The appearance of these three elements in the stories of Qur'an is not the same. One element can dominate in the narrative and other elements are almost invisible. The story element that stands out in the story of Prophet Sulaiman in the letter Şād verses 30-40 is a character or actor. The figure shown is the figure of Prophet Sulaiman. Verses 30-40 of Surah Şād tell about the figure of Prophet Sulaiman, the son of Daud, as the best servant who is very obedient to his God. God also praised Sulaiman for the behavior, attitude, manners, and so on that made him liked by many people before becoming a king. In addition, he was known to always be obedient, righteous, make driker and leave astray things from Allah.

The technique of describing the story of the Prophet Sulaiman in surah Şād verses 30-40 starts from a conclusion which is then followed by details or explanations from the first fragment to the final fragment. The story of Prophet Sulaiman in Surah Şād verses 30-40 begins with the conclusion that God praised Prophet Sulaiman as the best of servants. The first fragment, Prophet Sulaiman with his horse (verses 31-33). The second fragment, the test and repentance of Prophet Sulaiman (verses 34-35). The third fragment, God's gift to Sulaiman (verses 36-40). Meanwhile, the narrative of the Prophet Sulaiman in Surah Şād verses 30-40 on the artistic aspect.

Thus, this classical stylistic analysis emphasizes the level of linguistic aspects without presenting the context. This analysis does not relate much stylistics to context, but focuses more on linguistic aspects. It is different from the stylistic studies carried out by Western scholars who make stylistics a part of the chronological discussion. This pattern will be used by the author in studying Sulaiman's story. One of the nonMuslim scholars of Qur'an who built a theory of Qur'an chronology based on a study of the characteristics of his style ${ }^{25}$ or language style is Theodor Nöldeke. ${ }^{26} \mathrm{He}$ made the stylistic differences between the verses of the Qur'an and the periods of Mecca and Medina to be the source of the periodization of the history of the Qur'an. ${ }^{27}$ One form that distinguishes the stylistic verses of Qur'an in these two periods is related to 2017), 95.

${ }^{24}$ Syihabuddin Qalyubi, Tlm Uslub: Stilistika Bahasa dan Sastra Arab, (Yogyakarta: Idea Press,

${ }^{25}$ Emmanuelle Stefanidis, “The Qur'an Made Linear: A Study of the Geschichte Des Qorâns' Chronological Reordering", Journal of Qur'anic Studies, Vol. 10, No. 2, 2008, 1-22.

${ }^{26}$ Morteza Karimi-Nia, "The Historiography of the Qur'an in the Muslim World: The Influence of Theodor Nöldeke”, Journal of Qur'anic Studies, Vol. 15, No. 1, 2013, 46-68.

${ }^{27}$ Raymond K Farrin, “A Revised Inner-Qur'anic Chronology Based on Mean Verse Lengths and the Medina I Counting System”, Al Abhath, Vol. 67, No. 1, 2019, 1-29. 


\section{Arabiyât Jurnal Pendidikan Bahasa Arab dan Kebahasaaraban, 8 (1), 2021}

verse or style of verse in Qur'an. It is true that the poetry pattern has become a language culture rooted and developed in the pre-Islamic Arab society; as used by shamans or kuhān. ${ }^{28}$ Therefore, historically the style of poetry in Qur'an is related to the language culture at that time. ${ }^{29}$ However, the style of the al-Quran language still has its own characteristics (distinctive) ${ }^{30}$ than other Arabic literary works.

Meanwhile, based on modern statistical analysis, discussion of the rhetoric of Qur'an is influenced by a chronology that is in accordance with dynamic-historical reality and corresponds to the dynamic context faced by the Prophet Muhammad. There is correspondence between the rhetoric of Qur'an and the historical context that surrounds it, as seen in the historical content of Makiyah Madaniyah. The rhetorical study of the story of Prophet Sulaiman in Qur'an has historically been one of the representative objects. According to the chronological scheme of the letters offered by Theodor Nöldeke-Schwally, surah Shad verses 30-40 are included in the second period or mediaeval Mecca. The art of describing stories is a way inherent in the style of Qur'an language to describe an event, the psychological atmosphere through descriptions that can be felt and imagined based on the context of the verse. The middle period of Mecca is closest to the early of Mecca period which directly intersects with the pre-Islamic period, allowing the content of the style of the poetic language to still exist. ${ }^{31}$

One of the arts of describing stories in Surah Shad verses 30-40 is in the aspect of tone composition or poetry. The verses in this chapter tend to be short and brief. This short and concise surah is due to the fact that the verse-down phase (including in the second period or mediaeval Mecca) is indzar phase which its main priority is to influence the audience. Therefore, a focused and impressive language style is used. One of them is the language style in the form of a rhyme or rhyme with a beautiful poetic quality. In line with Angelika Neuwirth, who concluded that Makiyah's surahs have distinctive characteristics whichcan be classified into rhymed prose. ${ }^{32}$ From pre-Islamic to the 20 th century, poetry ${ }^{33}$ has continued to occupy an important

\footnotetext{
${ }^{28}$ James T Monroe, “Oral Composition in Pre-Islamic Poetry”, Journal of Arabic Literature, 1972, $1-53$.

${ }^{29}$ Abdullah Saeed, "Some Reflections on the Contextualist Approach to Ethico-Legal Texts of the Quran”, Bulletin of the School of Oriental and African Studies, 2008, 221-37.

30 Kais Dukes, Eric Atwell, and Nizar Habash, "Supervised Collaboration for Syntactic Annotation of Quranic Arabic", Language Resources and Evaluation, Vol. 47, No. 1, 2013, 33-62.

${ }^{31}$ Gustav Weil, “An Introduction to the Quran: III", The Biblical World, Vol. 5, No. 5, 1895, 343 59.

32 Angelika Neuwirth, "Structural, Linguistic and Literary Features", The Cambridge Companion to the Qur'an, 2006, 97-113.

${ }^{33}$ Sajak atau rbymed prose, merupakan jenis sastra yang berafiliasi dengan prosa, namun tidak sama dengan prosa. Prosa bahasanya lebih sesuai dengan arti leksikalnya dan memiliki ritme yang lebih besar; karakteristik prosa pada umumnya tidak bersajak, beritme dan berirama. Contoh prosa seperti hikayat, sejarah, kisah dan sebagainya. Letak perbedaan prosa dan sajak terletak aspek konstruksi ritme, sajak dan irama. Lihat Paul Starkey and Julie Scott Meisami eds., Encyclopedia of Arabic Literature: AJ; Volume II. KZ (Routledge, 1998). Lebih lanjut, Berque menjelaskan bahwa keberagaman bunyi sajak al-Qur'ān
} 


\section{Arabiyât Jurnal Pendidikan Bahasa Arab dan Kebahasaaraban, 8 (1), 2021}

position in Arabic literature and Arab society. ${ }^{34}$ The following are some of the rhymes found in Surah Shad Verses 30-40, namely:

Table.2 Rhymes in Chapter Şād Verses 30-40

\begin{tabular}{|c|c|c|}
\hline Verse & Redaction & Rhyme \\
\hline 30 & إنها أواب & /âb/ \\
\hline 31 & الصفنت الجياد & /âd/ \\
\hline 32 & توارت بالحجاب & /âb/ \\
\hline 33 & بالسوق والأعناق & /âq/ \\
\hline 34 & جسـدا ثم أناب & /âb/ \\
\hline 35 & إنك أنت الوهاب & /âb/ \\
\hline 36 & حيث أصاب & /âb/ \\
\hline 37 & كل بناء وغواص & /âsh/ \\
\hline 38 & في الأصفاد & /âd/ \\
\hline 39 & بغير حساب & $/ \hat{a b} /$ \\
\hline 40 & وحسن مئاب & /âb/ \\
\hline
\end{tabular}

The dimension of musicality contained in the letter Şād verses 30-40 (table 2) is dominant. Even so, musicality in the Qur'an has characteristics that are not similar as other literary works such as pre-Islamic Arabic poetry and prediction. This poem has had a role since pre-Islamic times and is widely used by shamans or kubhân but is not similar with poetry (parole of Qur'an) which not only displays harmony of sound but also harmony of other aspects such as harmony of phonemes, words, sentences and mean. The rhyme or sound of surah Şād verses 30-40 is still strong by showing

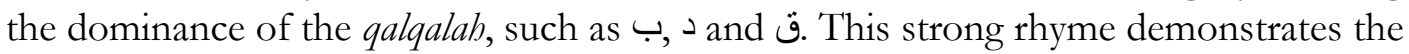
emphaticity of a focused and memorable style to influence the audience. The style of language that uses alternating strong and rhythmic qalqalah contains the power of expression in accordance with the context at that time (second period, mediaeval Mecca). This is due to the phenomena of magic and poetry in the Mecca period by

menunjukkan adanya perbedaan tujuan dan sasaran pada sebuah surat dalam al-Qur'ān. Lihat: Jacques Berque, Arabic Language Present, (Texas: Texas University Press, 1988).

34 Devin J Stewart, "Sajc in the Qur'an: Prosody and Structure", Journal of Arabic Literature, Vol. 21, No. 2, 1990, 101-39. 


\section{Arabiyât Jurnal Pendidikan Bahasa Arab dan Kebahasaaraban, 8 (1), 2021}

poets and magicians having a strategic position in society. Therefore, Qur'an seeks to outrank them through poetry.

The poetry pattern of surah Shad verses 30-40 generally contains the sound of qalqalah, producing an entertaining resonance in Arabic. At a vulnerable point, this surah has the characters of poetry /âb/, /âd/, /âb/, /âq/, /âb/, /âb/, /âb/, /âsh/, /âd/, / $\mathrm{ab} /$ and /âb/. In this poetry, a combination of vowels and consonants is used. In phonological studies, vowel sounds are considered sharper than consonant sounds. ${ }^{35}$ Vowels function to touch the audience's feelings, while consonants are a form of firmness. The harmony of this rhythm cannot be separated from the conditions when the verse was revealed; the mediaeval Mecca period which is adjacent to the early pre-Islamic Mecca. The harmony of the sound or rhythm that appears has an impact on the harmony or harmony of words (see table 2) such as harmony in the use of harokat so that it is easy to understand. In addition, the resulting rhythm at the end sound of this verse seems slow (a combination of long vowels $/ \bar{a} /$ and consonants). This slow or soft and serene rhythm shows the content of verses that contain lessons, expressions of Allah's gift to Prophet Sulaiman so that they can be entertainment for the Prophet Muhammad.

It is in line with what was conveyed by Muhammad 'Abd al-Zarqāni that the style of phoneme in Qur'an also has harmony in the arrangement of vowelsthat make it entertaining and easy to understand. ${ }^{36}$ This is proven by the explanation of the letter Shad verses 30-40 which has a matching vowel arrangement as in the words awwâb, wahbâb, ghawâsh. Then, the compatibility of the phoneme rhymes in the words al-Jiyâd, al-Hijâb, Hisâb. There is also the word al-A'nâq with al-Ashfâd and in the word Ma'âb with Anâb and Ashâb. The dominant vowel in this verse is the vowel alif (verses 3040), while the dominant consonant is ba phoneme in 7 verses, the phoneme in 2 verses, and the qaf and one verse shad phonemes. This harmony certainly shows the parole of Qur'an which is unique and different from the existing poetry in verse, prophecy and so on which appeared in pre-Islamic times and is formed simply by matching the final letter in two sentences. The harmony of the poetry built up in Qur'an is not only in the aspect of the similarity of the final sound, but also the harmony in several things ranging from phonemes, words, sentences to forming a harmony of meaning.

From the rhythmic patterns in the table above, it can be seen that the clearer rhyme arrangement is used. The harmony of the ending sounds or rhymes in this verse forms a pattern (A-B-A-C-A-A-A-D-B-A-A). The rhymes that appear are dominated by the consonant sound $b a(\varphi)$. Consonants symbolize assertiveness ${ }^{37}$, while vowels are used to touch the listener's feelings. ${ }^{38}$ The similarity of this sound is

35 Badrā Zahrān, Fi 'ilm al-Aswāt al-Lugawiyah wa 'Uyub al-Natq (Kairo: Dār al-Kutub, 1955), 123

36 Muhammad Afif Amrulloh, "Kesamaan Bunyi Pada Sajak (Kajian Fonologi Al-Qur'an Dalam Surat Al 'Asar)," Jurnal Al Bayan: Jurnal Jurusan Pendidikan Bahasa Arab 9, no. 1 (2017): 99-109.

37 Al-Badrāwī Zahrān, Fì 'ilm Al-Aṣwāt al-Lugawìya Wa- 'Uyūb al-Mantiq (Dār al-Ma'ārif, 1994).

38 Zayad Abd Rahman, "Angelika Neuwirth: Kajian Intertekstualitas dalam QS. Al-Rahman dan Mazmur 136", Empirisma: Jurnal Pemikiran dan Kebudayaan Islam, Vol. 24, No. 1, 2015. 


\section{Arabiyât Jurnal Pendidikan Bahasa Arab dan Kebahasaaraban, 8 (1), 2021}

the beauty of the musicality of Qur'an. ${ }^{39}$ One different consonant sound is then flanked by the same two consonant sounds and so on. The harmony of this sound shows the language style contains a beautiful poetic quality.

Even though it was the mediaeval Mecca period which was dominant with the scent of poetry, it did not absolutely follow the pattern of poets or the language culture developed in the Arab society at that time. Qur'an appears with the characteristics or uniqueness of its own language. Parole of Qur'an is manifested in the text of Qur'an itself which is not the same as human works. The matter of rhyme; appropriateness of the final sound at each piece of sentence ${ }^{40}$ in Qur'an is not the same as verse.

The sound of the end of the verse in the table above rhymes and gives prayer to engage the audience and show the power of expression or strong expression. Likewise, the similarity of wazan as in the choice of words contains the same diacritics (Jiyâd, Hijâb, Awâb, ghawâsh, awwâb). Thus the rhyme in Surah Şād verses 30-40 is still strong, thus showing that the language style is high with strong expressions in order to get influence from the listeners. The high style of language with strong poetry in this verse is not only to emphasize the intention but also to match the phenomena of magic and poetry at that time.

The verse content affects the consistency of the poetry in this chapter surah Shad verses 30-40. This surah focuses on one main objective and goal which is an important factor in tax consistency. One aspect of the goal that is focused on is the personality of Prophet Sulaiman. Although the description consists of two subjects, namely the first discussion about Sulaiman and his horses, the second discussion about struggle of Prophet Sulaiman's life. While the target focus on surah Şād verses 30-40 is Sulaiman. The consistency of this surah to one goal and target is an important point of the similarity of poetry in Surah Şād verses 30-40 which is dominated by the consonant $b a(ب)$ in almost all the ending sounds of each verse. The poetry that is built on surah Şād verses 30-40 is not the same as the existing poetry, prose and various other Arabic literary works such as those used in pre-Islamic Arabic society.

The presentation of the elements of the story in Surah Sad verses 30-40 which is dominated by a character or actor (Prophet Sulaiman) aims to provide moral strength and faith to the Prophet Muhammad and his followers. Highlighting actors in the story aims to entertain and motivate the Prophet Muhammad. This is in line with the historical setting at that time (Mediaeval Mecca or the second period) of the Prophet Muhammad was going through any temptation and dynamics of the prophet's preaching which often got rejection, pinched, torture and oppression to the expulsion of the prophet from Mecca. ${ }^{41}$ Moreover, Prophet Muhammad was in grief after the

${ }^{39}$ Muhammad Afif Amrulloh, "Kesamaan Bunyi Pada Sajak (Kajian Fonologi al-Qur'an Dalam Surat al "Asar)".

${ }^{40}$ Sayyid Ahmad Hashimi, Jawāhir al-Balägah fĩ al-Bayān wa al-Mä'ani wa al-Badĩ', (Beirut: Maktabah 'Ashriyah, 1990), 330.

${ }^{41}$ Tazul Islam, "De-Radicalization Of Jihadism: An Analysis Of Maqasid Approach”, 2020. 


\section{Arabiyât Jurnal Pendidikan Bahasa Arab dan Kebahasaaraban, 8 (1), 2021}

death of Siti Khadija ${ }^{42}$ and Abu Talib, so that the story of Sulaiman's personality can comfort the sadness of the Prophet Muhammad.

The language style of Surah Şād verses 30-40 is also influenced by the psychological atmosphere and social context of the Arabs. At that time, there was an elite group who liked to reject and suppress the prophet and his followers. Therefore, this verse uses a language style that is comforting and motivates Prophet Muhammad. It is a short but emotional redaction. The personality of Prophet Sulaiman as a prophet and king $^{43}$ with a strong rhyme that was able to strengthen the heart of Prophet Muhammad in facing the tough dynamics when preaching in Mecca. In addition, this language style is also used to dispel doubts or strengthen the heart of Prophet Muhammad to remain calm and patient in facing the sadness and cruelty of the people of Mecca. Thus, the structure of the story of Prophet Sulaiman in this verse shows the strengthening of human faith with the theme of fundamental teachings plus illustrations from the natural and historical past as values to be conveyed.

The choice of words that represent God's name using divine attributes is emphasized, such as the use of Rabb and anta al-Wabhab. The use of the adjective God shows a deep meaning, without having to explain in length to show God's power and compassion. The purpose of presenting the signs of God's power and the mention of this divine nature serves to entertain the Prophet Muhammad for the grief experienced by emphasizing God's presence on the sign of power along with his divine nature as a place to solve all problems. In addition, it also functions as a threat to the Quraish of Mecca who strongly rejects ${ }^{44}$ and did not believe the prophet's invitation.

Furthermore, the analysis related to langue and parole, that in the context of presenting the elements of the story in Surah Shad (38) Verses 30-40, is dominated by elements of character or characterization (Sulaiman). Thus, Arabic as langue; a language convention or a system of rules used in the telling of the story. Meanwhile, the dominance in the presentation of the elements of the story in the characterization or character aspect (Sulaiman) is the parole of Qur'an. The parole dimension (characterization) in Qur'an is manifested in a distinctive way in the description of Qur'an text. Of course, the parole of Qur'an in its delivery follows the chronological dimension of the historical setting of the community when the verse was revealed.

In the context of the art of describing stories in Surah Shad (38) Verses 30-40 include several things, namely the aspect of the composition of the tone or poetry (rhyme) which is strong and the short verses. Therefore, Arabic, as langue is a language convention or a system of rules used in the telling of the story. Meanwhile, the dominance in the art of describing stories in the musical aspects (high rhymes) and

\footnotetext{
${ }^{42}$ Nooria Mehraby, "Psychotherapy with Islamic Clients Facing Loss and Grief', Psychotherapy in Australia, Vol. 9, No. 2, 2003.

43 Jules Janssens, "The Ikhwan Aș-Ṣafa' on King-Prophet Solomon”, in The Figure of Solomon in Jewish, Christian and Islamic Tradition (Brill, 2013), 241-53.

${ }^{44}$ Suleman Essop Dangar, "The Career of Abu Sufyan before and after His Conversion to Islam", 1987.
} 


\section{Arabiyât Jurnal Pendidikan Bahasa Arab dan Kebahasaaraban, 8 (1), 2021}

short verses is the parole of Qur'an. Finally, the context of the story telling technique begins with a summary of the story which is then followed by details or explanations from the first to the final fragment.

\section{Conclusion}

In many studies, Qur'an is considered as a symbol of the unique communication from God to humans; independent of the previous and subsequent categories of Arabic speech. Qur'an contains Arabic literature unique to its own narrative style. In the study of the stylistics of Qur'an, there are two views from Muslim scholars / classical scholars and Western / modern scholars. Classical stylistics focuses more on linguistic aspects without connecting with context. It is different from the modern stylistics developed by Western scholars who make part of the discussion of chronology as Qur'an stylistics so that they pay attention to certain relationships with contexts. Based on classical stylistics, in Surah Shad (30-40) we find the use of the form Shigat Mubâlagah (Morphological Aspects; al-mustawâ al-sharfi), as in the word awwâb in verse 30, the word al-Wahhâb in verse 35 words gawâsh. However, this analysis only touches on a linguistic level, not on context. Meanwhile, modern stylistic analysis relates more style to context. This study of the language style of Qur'an is different from the studies of other Muslim scholars who only focus on the text, not the chronological context of surah.]

\section{REFERENCES}

Abdul Majid, Latifah., Nurul Mukminah Zainan Nazri, Wan Nasyrudin Wan Abdullah, Aminah Abdullah, and Fadlan Mohd Othman. "Attributes of Antioxidants as Inferred from the Makki and Madani Verses of the Qur' an", Al-Burhan: Journal of Qur' an And Sunnab Studies, Vol. 4, No. 1, 2020.

Ahmed, Mohammed Nihad. "The Issue of Translating Cognitive Semantic Content of Discourse", Journal of Tikerit University for the Humanities, Vol. 17, No. 7, 2010.

Amrulloh, Muhammad Afif. "Kesamaan Bunyi Pada Sajak (Kajian Fonologi Al-Qur'an Dalam Surat Al "Asar)", Jurnal Al Bayan: Jurnal Jurusan Pendidikan Bahasa Arab, Vol. 9, No. 1, 2017.

Cuypers, M. "Semitic Rhetoric as a Key to the Question of the Nazm of the Qur'anic Text", Journal of Qur'anic Studies, Vol. 13, No. 1, 2011.

Dangar, Suleman Essop. "The Career of Abu Sufyan before and after His Conversion to Islam”, 1987.

Dukes, Kais., Eric Atwell, and Nizar Habash. "Supervised Collaboration for Syntactic Annotation of Quranic Arabic", Language Resources and Evaluation, Vol. 47, No. $1,2013$.

Farrin, Raymond K. “A Revised Inner-Qur' anic Chronology Based on Mean Verse Lengths and the Medina I Counting System", Al Abhath, Vol. 67, No. 1, 2019. 


\section{Arabiyât Jurnal Pendidikan Bahasa Arab dan Kebahasaaraban, 8 (1), 2021}

Haleem, M A S Abdel. "The Role of Context in Interpreting and Translating the Qur'an", Journal of Qur'anic Studies, Vol. 20, No. 1, 2018.

Hassan, Shahir Akram. "Understanding Social Phenomenon from Qur'anic Verses", The Macrotheme Review, Vol. 3, No. 4, 2014.

Ibnorrasool, Sayyed Mohammad Reza, and Azam Dehghani. "Extra Letters in Osman Taha Line Their Positions and Their Causes in the Quran", Studies on Arabic Language and Literature, Vol. 4, No. 14, 2013.

Islam, Tazul. "De-Radicalization of Jihadism: An Analysis of Maqasid Approach", 2020.

Jaafar, Eman Adil. "A Stylistic Analysis of Two Selected Poems", Journal of the College of Education for Women, Vol. 25, No. 1, 2014.

Janssens, Jules. "The Ikhwan Aș-Ṣafa' on King-Prophet Solomon”, In The Figure of Solomon in Jewish, Christian and Islamic Tradition, Brill, 2013.

Karimi-Nia, Morteza. "The Historiography of the Qur'an in the Muslim World: The Influence of Theodor Nöldeke", Journal of Qur'anic Studies, Vol. 15, No. 1, 2013.

Khan, Mohd Imran. "Stylistic Dimensions in Translations of the Holy Quran into English with Special Reference of Surah Al-Fatiha", Journal of Education, Society and Behavioural Science, 2016.

Khusna, Azalia Mutammimatul. "Kisah Nabi Sulaiman AS dalam Al-Qur'an (Analisis Stilistika)", Thesis, UIN Sunan Kalijaga Yogyakarta, 2019.

Machmudah, Umi., Achmad Nurcholis, Yusuf Hanafi, and Moh Khasairi. "Epitome Solution to Nahw Instruction: Strategies toward i'rab Reading Abilities for Students", International Journal of Innovation, Creativity and Change, 2020.

Mahazi, Muhammad Afiq, and Hakim Zainal. "Asas Pembentukan Kata Dalam Morfologi Arab: [The Foundation on Word Formation In Arabic Morphology]." Ulum Islamiyyah 25 (2018): 55-63.

Matswah, Akrimi. "Mustansir Mir and a Contemporary Literary Approach to the Qashash Al-Qur'an: Study of Qur'anic Story of Joseph", Ulumuna, Vol. 21, No. 2, 2017.

Mehraby, Nooria. 'Psychotherapy with Islamic Clients Facing Loss and Grief', Psychotherapy in Australia, Vol. 9, No. 2, 2003.

Melhem, Laith Bany., Mohd Sanusi Azmi, Azah Kamilah Muda, Nazieh Jamil BaniMelhim, and Mohammed Alweshah. "Text Line Segmentation of Al-Quran Pages Using Binary Representation”, Advanced Science Letters, Vol. 23, No. 11, 2017.

Monroe, James T. "Oral Composition in Pre-Islamic Poetry", Journal of Arabic Literature, 1972.

Mursalim. "Gaya Bahasa Pengulangan Kisah Nabi Musa As. dalam Al-Qur'an: Suatu Kajian Stilistika”, Lentera, Vol. 1, No. 1, 2017. 


\section{Arabiyât Jurnal Pendidikan Bahasa Arab dan Kebahasaaraban, 8 (1), 2021}

Nahar, Muhammad Hasnan. "Antagonist Figures in the Qur'anic Stories”, Afkearuna: Indonesian Interdisciplinary Journal of Islamic Studies, Vol. 15, No. 2, 2019.

Neuwirth, Angelika. "Structural, Linguistic and Literary Features", The Cambridge Companion to the Qur'an, 2006.

Padwisana, Nur., Moh Abdul Kholiq Hasan, and Ari Hikmawati. "Gaya Bahasa Komunikasi Dakwah Nabi Sulaiman dengan Ratu Negeri Saba' dan Para Pembesar dalam Al-Qur'an”, 2017.

Rahman, Zayad Abd. "Angelika Neuwirth: Kajian Intertekstualitas Dalam Qs. AlRahman dan Mazmur 136”, Empirisma: Jurnal Pemikiran dan Kebudayaan Islam, Vol. 24, No. 1, 2015.

Rashid, Haleema., and Muhammad Arfan Lodhi. "Stylistics Analysis of the Two Translated Versions of the Holy Quran with Special Reference of Surah AlNoor”, Sciences, Vol. 6, No. 2, 2018.

Saeed, Abdullah. "Some Reflections on the Contextualist Approach to Ethico-Legal Texts of the Quran", Bulletin of the School of Oriental and African Studies, 2008.

Sedghi, Hamed., and Fatemeh Ganjkhnlou. "An Analysis of the Narrative Structure of the Story of Prophet Sulaiman (AS) and Queen of Saba Based on Greimas's Narrative Model”, Literary Quranic Researches, Vol. 4, No. 3, 2016.

SICAK, Ahmet Sait. “Kur'ân'da Benzer Mana ve Lafizlarda Tefennün”, Cumburiyet Ilabiyat Dergisi, Vol. 23, No. 2, n.d.

Stefanidis, Emmanuelle. 'The Qur'an Made Linear: A Study of the Geschichte Des Qorâns' Chronological Reordering”, Journal of Qur'anic Studies, Vol. 10, No. 2, 2008.

Stewart, Devin J. "Sajc in the Qur'an: Prosody and Structure", Journal of Arabic Literature, Vol. 21, No. 2, 1990.

Sunny, Suniarti. "Gaya Bahasa Dalam Surat Ar Rahman (Kajian Stilistika)”, Tesis, UIN Sunan Kalijaga Yogyakarta, 2014.

Weil, Gustav. “An Introduction to the Quran: III”, The Biblical World, Vol. 5, No. 5, 1895. 